\title{
砂とセメント安定処理砂の簡易なひずみ軟化型構成式 A SIMPLE CONSTITUTIVE EQUATION FOR SANDS AND CEMENT-TREATED SANDS WITH STRAIN-SOFTENING
}

\author{
山田雅一*, 安達俊夫** \\ Masaichi YAMADA and Toshio ADACHI
}

\begin{abstract}
This study is related to the modeling of the nonlinear stress-strain behavior of frictional materials for wide range of strain. To describe both strain-hardening and also strain-softening behavior, a constitutive equation including a power term is proposed in the following. This equation is shown to offer more versatility for modeling stress-strain behavior in monotonic loading conditions, at from low- to high-strain levels. The proposed equation is relatively verified by experimental data of hollow cylindrical torsional shear tests on both sands as frictional materials, and cement-treated sands as frictional and cohesive materials. In addition, a exponential function is adopted to express the stress-dilatancy relations of cement-treated sands. A dilatancy characteristics of sands and cement-treated sands is expressed by using both functions together.
\end{abstract}

Keywords : Sand, Soil cement, Torsional shear,Constitutive equation,Stress-strain relation, Strain softening,Dilatancy 砂, ソイルセメント, ねじりせん断, 構成式, 応力ーひずみ関倸, ひずみ軟化, ダイレイタンシー

\section{1.はじめに}

基礎構造物の設計法を取り巻く現状は，世界的に仕様設計から性 能設計に移行しつつあり, 小変位から大変位までの連続的な変形の 把握と評価が急務となってきており，広範囲なひずみ領域における 適切な応力ーひずみ関係を表現する構成式の開発，ならびにこれら を用いた地盤の変形予測の重要性が高まってきている.

地盤材料の実測した応力ーひずみ関倸を定式化するには，その構 成式が簡明でかつ一般性があり, 個々のデータのフィッティングの 精度が高いことが望まれる. また, 構成式のパラメータの数は少な く, 原位置試験と室内土質試験によりパラメータを決定できる必要 がある ${ }^{1)}$.

土の非線形な忍力ーひずみ関倸を表現する代表的なものに， Kondner ${ }^{2.3)}$ )の提案した双曲線モデルがある.このモデルは, 応力ー ひずみ関保を直接的に近似する手法により定式化されたモデルであ り実務でも用いられているが，一方では龍岡ら 4)によって, 各種地 盤材料に対する双曲線モデルと実測デー夕の適合性が調べられ，ほ とんどの地盤材料において両者は一致しないことが指摘されている. また, 実際に, これまでに双曲線モデルに派生した多くの非線形モ デルが提案されている. 例えば, 試験データのフィッティングの精 度を高めるために, Hayashi ら 5), Prevost ら "), Griffiths ら 7),
龍岡ら 1).8)によって, 双曲線モデルを修正したモデルが提案されて いる.この中で, 龍岡ら 1).8)が提案した GHE モデルは, 微小ひずみ レベルから最大強度に到るまでの平面ひずみ圧縮試験による試験結 果を良く近似できることが示されている，また，Duncan らッは， Kondner (2).3)の双曲線モデルを用い FEM 解析に適用している. Towhata ら 10)は, 双曲線モデルを用いて主応力軸の回転による影響 を考虑できる Multi-Spring モデルを提案している：この他にも， 非線形な応力ーひずみ関倸を表現するモデルには，RambergOsgood モデル, Iwan モデル ${ }^{11}$, Jardine ら 12)のモデル, Goto ら 13)のモデルなどがある. Ramberg-Osgood モデルは, 最初に

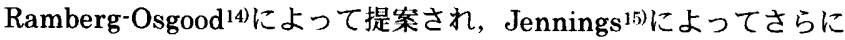
一般性を持たせるために改良された自由度の高いモデルで, 線形項 にべき関数による非線形項を加えた指数関数型モデルである. Iwan モデル ${ }^{11}$ は，強度の異なる多数の弾・完全塑性タイプのばねを並列 に並べたもので, 双曲線モデルと比べると忍力ーひずみ関係を近似 するときの自由度が高いモデルである. Jardine ら 12)のモデルは， 粘性土の非排水三軸圧縮試験結果に基づき定式化された余弦関数と 対数関数の併用型モデルであり，広範囲なひずみ領域での応力ーひ ずみ関係を近似できるのが特徴である. Goto ら 13)のモデルは，応 カーひずみ関倸を弾性領域と非線形領域に分割し，非線形領域に正

\footnotetext{
本論文の一部は，参考文献34＜wide>３7）に発表した。

*日本大学理工学部建築学科 助手・工修

** 日本大学理工学部建築学科 教授 $\cdot$ 工博
}

Assistant, Dept. of Architecture, College of Science \& Technology, Nihon University, M. Eng.

Prof., Dept. of Architecture, College of Science \& Technology, Nihon University, Dr. Eng. 
弦関数と対数関数の併用型モデルを用いている

ところで, 密な砂, 過压密粘土, 軟岩および文定処理土をせん断 すると，それらの志力ーひずみ関係にはひずみ硬化のみならず，ひ ずみ軟化現象が観察される，ひずみ軟化現象とは，せん断により忘 力が増加して最大強度に達して，その後減少に転じて最終的には大 ひずみで残留強度に到達する現象であり, せん断変形の進行ととも にダイレイタンシーが生じる. また，ひずみ軟化現象は, 地盤 $\mathrm{I}$ 学 の諸問題で論じられている進行性破壊と密接に関連すると考えられ ていることから,その挙動を表現できる構成式の確立は重要となる. しかしながら，前述した非線形モデルではこの最大強度後のひずみ 軟化举動を表現することができない，一方では，地盤材料のより複 雑な挙動を表現するために弾塑性理論に基づいた構成式が多く提案 されている例えば 1(i) 〜201．しかしながら，それらにはそれぞれに多様な 特徴があり比較的厳密な土の挙動を再現できるものの, 前述した一 般性があるとは言えないようである．また，簡易な構成式に比べて パラメータ数が多くなり，そのパラメー夕を決定するには空内土質 試験などに基づく多くの精緻な土質情報が必岀不叮欠となる.

このような背景から，本論文では，地盤材料に対する公範岄なひ ずみ領域で，ひずみ硬化のみならずひずみ軟化の心力ーひずみ関倸 を表現できる簡易な非線形モデルを捉案し，ここでは，摩擦性材料 である砂と粘着成分を有する摩擦性材料であるセメント改良砂に対 する中空ねじりせん断試験結果による心力ーひずみ関係について捉 案モデルと双曲線モデルを適用して雨モデルを比較検垨した．さら に, 砂とセメント改良砂のダイレイタンシー特性を表現するために， 砂に対しては既往のストレス・ダイレイタンシー関倸 21 'を开い, セメント改良砂については中空ねじりせん断試験結果に基づいたス トレス・ダイレイタンシー式を提案し，これらストレス・ダイレイ タンシー関倸と，提案した忠力ーひずみ関係を併为することによっ て砂とセメント改良砂のダイレイタンシ一特性を表垷できることを 手した.

\section{2. 非線形モテル}

\section{1 双曲線モテルと提案モテル}

地盤材料の応力ーひずみ関係の最大の特徵は, 小ひずみでの非線 形性にあり, 最大強度以前の応力ーひずみ関倸に対しては, 双曲線 関係でおおよそ近似できることが知られている. Kondner ${ }^{2) .39}$ は粘性 土と砂の三軸試験結果から得られた主応力差一軸ひずみ関係を表現 するために(1)式の双曲線関倸を提案した.

$$
\begin{aligned}
& \sigma_{1}-\sigma_{3}=\frac{\varepsilon}{\mathrm{a}+\mathrm{b} \varepsilon} \\
& \text { ここに, } \sigma_{1}-\sigma_{3} \text { は主忍力差, } \varepsilon \text { は軸ひずみ, } 1 / \mathrm{a} \text { は初期接線係数, }
\end{aligned}
$$

$1 / \mathrm{b}$ は破壊応力である.

Hardin·Drnevich ${ }^{22)}$ は，粘性土と砂の主に共振法土質試験から得

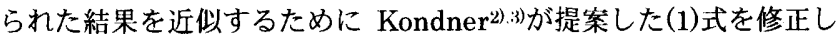

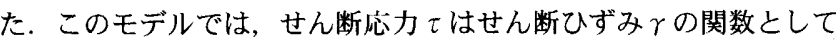
(2)式で表されている.（2)式中の $\tau_{\max }$ は破壊応力であり，(3)式で定 義される。

$$
\tau=\frac{\gamma}{\frac{1}{G_{\max }}+\frac{\gamma}{\tau_{\max }}}
$$

$$
\tau_{\max }=\mathrm{G}_{\max } \gamma_{\mathrm{r}}
$$

ここに， $\mathrm{G}_{\mathrm{max}}$ 注初期せん断弾性倸数， $\gamma_{\mathrm{r}}$ は規準ひずみと定義さ れる.

(1)式と(2)式の構成式は基本型が同一であり, Kondner ${ }^{21.3)}$ は単調 載荷試験による忍力ーひずみ関倸を表し，Hardin- Drnevich ${ }^{22)}$ は 繰这し載荷試験による心力ーひずみ関係を表している. しかしなが ら, Kohata ら 23)は, 供試体端面とキャップおよびペデスタル面と の不完全接触で生じるベディングエラー24)を取り除いた局所軸ひず み測定法に基づく数種類の粗粘土と唯積㳄岩を対象とした排水三軸 厈縮試験結果から，(1)式に示した初期接線係数は最人ヤング係数で はなく, 最大ヤング係数は軸忍力に低存して大きくなることを報告 している.このことより，地盤材料の種類によっては，(1)式と(2) 式の心カーひずみ関係で雨者の非線形性が恭なることに留意しなけ ればならない。

本論文で提案する非線形モデルは, 微小ひずみレベルから最大強 度以降の大ひずみまでの広範明なひずみ領域における心力ーひずみ 関係を表現できる構成式である，提案モデルの心力ーひずみ関係を (4)式で表す. 提案モデルは, 地盤材料の心力ーひずみ関係の非線形 性とひずみ㹬化ならびにひずみ吹化を表現するために，べき来数を 導入した非線形項を有する指数関数型モデルであり，尘測した試験 データのフィッティングの精度を高めるために, 双曲線モデルを拡 张したものである.

$$
\tau=\mathrm{aG}_{\max }\{1-\mathrm{R}(\gamma)\} \gamma
$$

ここに, $\mathrm{a}$ は補正倸数であり 1 とは限らない， $\mathrm{R}(\gamma)$ は(5)式と定義 する.

$$
R(\gamma)=\frac{\left(\frac{\gamma}{\gamma_{\mathrm{r}}}\right)^{\mathrm{C}}}{\left[1+\left(\frac{\gamma}{\gamma_{\mathrm{r}}}\right)^{\mathrm{C}}\right]^{\mathrm{D}}}
$$

ここで，(5)式中のべき乗 $\mathrm{C}, \mathrm{D}$ の変化に対する $\mathrm{R}(\gamma)$ と $\gamma / \gamma_{\mathrm{r}}$ の 関倸を図-1(a)，(b)に示した. 図-1(a)は $\mathrm{D}=1.0$ として $\mathrm{C}=1.0$ を中心 に 0.05 刻みで変動させた場合の $\mathrm{R}(\gamma)$ の変化を示し, 図-1(b)は $\mathrm{C}=1.0$ で $\mathrm{D}=1.0$ を中心に $\mathrm{D}$ の值を変動させた場合に対する $\mathrm{R}(\gamma)-$ $\gamma / \gamma_{\mathrm{r}}$ 関係を示している. 両図より, べき乗 C は主として非線形性

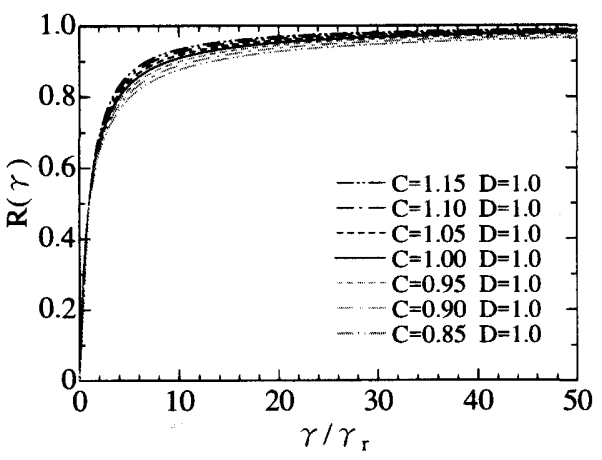

図-1(a) $R(\gamma)-\gamma / \gamma_{\mathrm{r}}$ 関係

$(\mathrm{C}=0.85 \sim 1.15, \mathrm{D}=1.0)$ 


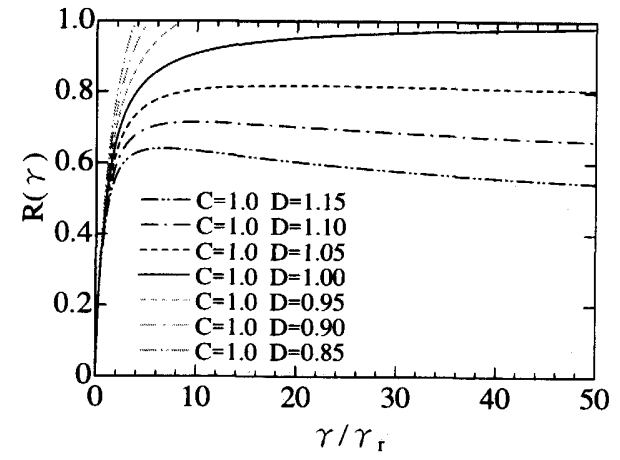

図-1(b) $\mathrm{R}(\gamma)-\gamma / \gamma_{\mathrm{r}}$ 関係

$(\mathrm{C}=1.0, \mathrm{D}=0.85 \sim 1.15)$

を規定するパラメータ, ベき乗 D は主としてひずみ硬化およびひず み軟化を規定するパラメータと定義される。

また, 規準ひずみ $\gamma_{\mathrm{r}}$ は $\tau_{\max }$ と $\mathrm{G}_{\max }$ に補正係数を乗じた $(6)$ 式と定 義する.

$$
\gamma_{\mathrm{r}}=\frac{\mathrm{b} \tau_{\max }}{\mathrm{aG}}
$$

ここに, b は補正倸数である.

(4)式において, $\mathrm{A}=1 /\left(\mathrm{aG}_{\mathrm{max}}\right), \mathrm{B}=1 /\left(\mathrm{b} \tau_{\text {max }}\right)$ とおくと提案モデルは (7)式で表される.

$$
\tau=\frac{\gamma}{\mathrm{A}}\left\{1-\frac{\left(\frac{\mathrm{B} \gamma}{\mathrm{A}}\right)^{\mathrm{C}}}{\left[1+\left(\frac{\mathrm{B} \gamma}{\mathrm{A}}\right)^{\mathrm{C}}\right]^{\mathrm{D}}}\right\}
$$

(7)式において $\mathrm{C}=1, \mathrm{D}=1$ とおけば，提案モデルは(8)式となり，双 曲線モデルに帰着することになる。

$$
\tau=\frac{\gamma}{\mathrm{A}+\mathrm{B} \gamma}
$$

従って, 提案モデルのパラメータは, $\mathrm{G}_{\max }, \tau_{\text {max }}, \mathrm{a}, \mathrm{b}, \mathrm{C}, \mathrm{D}$ となる. 一方, 双曲線モデルのパラメー夕は提案モデルと同様に規 準ひずみ $\gamma_{\mathrm{r}}$ に補正倸数を考慮すると， $\mathrm{G}_{\mathrm{max}}, \tau_{\mathrm{max}}, \mathrm{a}, \mathrm{b}$ である。 後述する排水せん断試験のシミュレーション解析では，規準ひずみ に補正係数を考慮した双曲線モデルで検討した.

また, 提案モデルをせん断応力比 $\tau / \sigma^{\prime}{ }_{\mathbf{m}}$ 一せん断ひずみ $\gamma$ 関係で 表現すると(9)式となる.

$$
\frac{\tau}{\sigma_{\mathrm{m}}^{\prime}}=\frac{\mathrm{aG}_{\max }}{\sigma_{\mathrm{m}}^{\prime}}\{1-\mathrm{R}(\gamma)\} \gamma
$$

ここに, $\sigma^{\prime}{ }_{\mathrm{m}}$ は平均有効主応力である.

(9)式において, $\mathrm{A}=1 /\left(\mathrm{aG}_{\max } / \sigma^{\prime}{ }_{\mathrm{m}}\right), \mathrm{B}=1 /\left(\mathrm{b}\left(\tau / \sigma^{\prime}{ }_{\mathrm{m}}\right)_{\text {max }}\right)$ とおくと (10)式となる.

$$
\frac{\tau}{\sigma_{\mathrm{m}}}=\frac{\gamma}{\mathrm{A}}\left\{1-\frac{\left(\frac{\mathrm{B} \gamma}{\mathrm{A}}\right)^{\mathrm{C}}}{\left[1+\left(\frac{\mathrm{B} \gamma}{\mathrm{A}}\right)^{\mathrm{C}}\right]^{\mathrm{D}}}\right\}
$$

一方, 双曲線モデルを $\tau / \sigma^{\prime}{ }_{\mathrm{m}}-\gamma$ 関係に適用すると(11)式になる.

$$
\frac{\tau}{\sigma_{\mathrm{m}}}=\frac{\gamma}{\frac{\sigma_{\mathrm{m}}}{\mathrm{aG}}+\frac{\gamma}{\mathrm{b}\left(\tau / \sigma_{\mathrm{m}}^{\prime}\right)_{\max }}}
$$

(11)式において，提案モデルと间じように $\mathrm{A}=1 /\left(\mathrm{aG}_{\max } / \sigma^{\prime}{ }_{\mathrm{m}}\right)$, $\mathrm{B}=1 /\left(\mathrm{b}\left(\tau_{\max } / \sigma^{\prime}{ }_{\mathrm{m}}\right)_{\max }\right)$ とおくと(12)式となる.

$$
\frac{\tau}{\sigma_{\mathrm{m}}^{-}}=\frac{\gamma}{\mathrm{A}+\mathrm{B} \gamma}
$$

(9)式において $\mathrm{C}=1, \mathrm{D}=1$ とおけば,提案モデルは(12)式で表され， 双曲線モデルと闹じになる．

\section{2 各種地盤材料への適用例}

図-2は, 佐藤ら 25)と涵谷ら2(6)による平面ひずみ圧縮試験および三 軸圧縮試験で得られた各種地盤材料に対する最大強度以前の $\mathrm{E}_{\mathrm{sec}}$ $\mathrm{E}_{\max }$ と $\mathrm{q} / \mathrm{q}_{\max }$ の関係を示したものであり, 地盤材料の種類によって 非線形性が異なっていることがわかる．ここに， $\mathrm{E}_{\text {xee: }}$ は割線ヤング 係数, $\mathrm{E}_{\max }$ は初期最大ヤング係数， $\mathrm{q}$ は偏差応力, $\mathrm{q}_{\max }$ は最大偏差 応力であり, $\mathrm{Y}=\mathrm{q} / \mathrm{q}_{\mathrm{max}}, \mathrm{X}=\gamma / \gamma_{\mathrm{r}}$ として試験結果が整理されたもの である.ここで, 提案モデルを $\mathrm{Y}=\tau / \mathrm{b} \tau_{\text {max }}, \mathrm{X}=\gamma / \gamma_{\mathrm{r}}$ とおいて, $\mathrm{Y} / \mathrm{X}$ と $\mathrm{Y}$ の関係を図-2に示した平面ひず夕圧縮試験および三軸圧縮 試験結果に当てはめて, 各種地盤材料の試験デー夕を提案モデルで 近似して同図中に奏線で併せ示した，また，図中の破線は補正係数 $\mathrm{a}$ と b が 1 のときの双曲線モデル,すなわち(1)式に示した Kondner の双曲線モデル(ここでは，原型双曲線モデルと呼ぶことにする．) を示しており，磷の忍力ーひずみ関係については原型双曲線モデル で近似できるようである，また，図中にはデータが示されていない が硬岩の場合も原型双曲線モデルが適用できるようである 27 . 図-2 より, 提案モデルは, 各種地盤材料に対して最大強度以前の応力一 ひずみ関係を表現できることがわかる.

本論文では，図-2に示したせん断挙動が大きく異なる摩摖性材料 である自然砂と, 砂と岩の中間的な力学挙動を呈する粘着成分を有 する摩摖性材料であるセメント改良砂の中空ねじりせん断試験によ る排水単調載荷試験結果に提案モデルと双曲線モデルを適用して両 モデルを比較検討した.

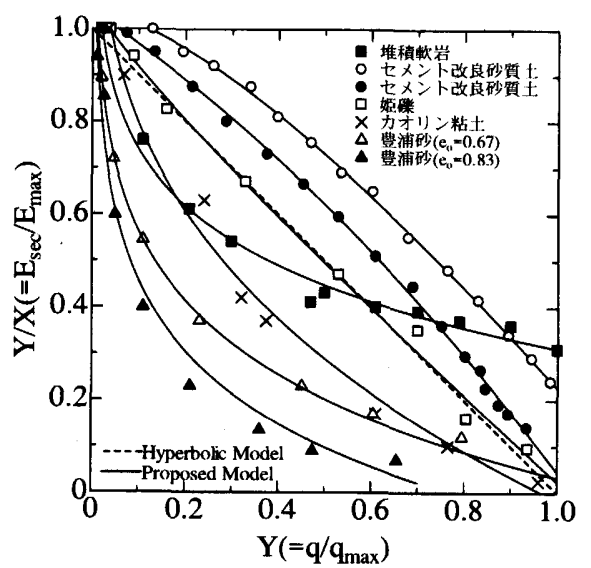

図-2 各種地盤材料の $\mathrm{Y} / \mathrm{X}\left(=\mathrm{E}_{\mathrm{sec}} / \mathrm{E}_{\max }\right)$ と $\mathrm{Y}\left(=\mathrm{q} / \mathrm{q}_{\max }\right)$ の関係 ${ }^{25), 26)}$

\section{3. ストレス・ダイレイタンシー関係}

せん断中の体積変化特性を表現する式としてストレス・ダイレイ タンシー式がよく使われる. Rowe ${ }^{211}$ は, 粒状体の変形機構を微視的 
観点から調べ, せん断中の主心力比と主ひずみ增分比の関係式をス トレス・ダイレイタンシー式と呼んだ。このような忍力比ーひずみ 増分比関倸は, 地盤材料の構成式を構築する際によく利用される関 係式の一つである．また, この関倸は同一の土ならば，密度，压密 机力，構造異力性の影響を基本的には受けないことが実験的に示さ

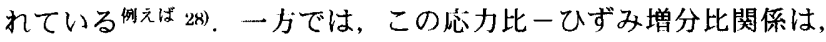
Shamoto ら※によって, ピーク強度に至るまでは忘力径路とひずみ 径路の影響を受けることも報告されている.

このストレス・ダイレイタンシー式は，平而ひずみ状態では(13) 式で表される。

$$
\frac{\dot{\sigma_{1}}}{\overrightarrow{\sigma_{3}}}=\mathrm{K}\left(-\frac{\mathrm{d} \varepsilon_{3}}{\mathrm{~d} \varepsilon_{1}}\right)
$$

ここに， $\sigma^{\prime}{ }_{1} ， \sigma_{3}^{\prime}$ はそれぞれ最大主忍力，最小主心力であり， $\mathrm{K}$ は材料定数, $\mathrm{d} \varepsilon_{1}$ は最大主ひずみ増分, $\mathrm{d} \varepsilon_{3}$ は最小主ひずみ增分で ある

単純せん断変形状態で，せん断忍力比を平均有効主志力 $\sigma_{\mathrm{m}}^{\prime}$ で表 すと(14)式となる。

$$
\frac{\tau}{\sigma_{\mathrm{m}}}=\mathrm{K}\left(-\frac{\mathrm{d} \varepsilon_{\mathrm{v}}}{\mathrm{d} \gamma}\right)
$$

ここに, $\mathrm{d} \varepsilon 、$ は体積ひずみ増分, $\mathrm{d} \gamma$ はせん断ひずみ増分である. 図-3に，中空ねじりせん断試験による異方心力条件ドでの自然砂 とセメント改良砂の $\tau / \sigma^{\prime}{ }_{\mathrm{m}}--\mathrm{d} \varepsilon_{\mathrm{v}} / \mathrm{d} \gamma$ 関保の試験結果:(1)を示し た. 試験に用いた試料は, 茨城県庇嶋市で採取した白然砂である. 自然砂の物理的性質を表-1に, 粘径加積曲線を図-4に示す. 中空门 筒供試体の寸法は，外径 $10 \mathrm{~cm}$, 内径 $6 \mathrm{~cm}$, 高さ $10 \mathrm{~cm}$ である. 自 然砂は相対密度が Dr 密店力比 $\mathrm{K}=0.4$ の排水ねじりせん断試験結果であり, セメント改良 砂は鹿嶋砂をセメント系固化材により安定処理した（因化材添加量 $\mathrm{C}=50 \mathrm{~kg} / \mathrm{m}^{3}$, 水・固化材重量比 W/C $=100 \%$, ベントナイト・团化 材重量比 $\mathrm{B} / \mathrm{C}=3 \%$; 液状化対策として適用される強度レベルで一軸 圧縮強度は約 $120 \mathrm{kN} / \mathrm{m}^{2}$ である.）改良砂の買方圧密忍力比 $\mathrm{K}=0.4$ の条件下における試験材跘 7 日の排水ねじりせん断による試験結果 である. 図-3より, 自然砂の $\tau / \sigma{ }_{\mathrm{m}}--\mathrm{d} \varepsilon_{\mathrm{v}} / \mathrm{d} \gamma$ 関倸は, デー夕 に多少のばらつきが見られるものの，圧密応力の影響を受けていな いことがわかる．また，試験結果はせん断に伴い体積収緶から体積 膨張の変化を示しているため，(14)式に示したストレス・ダイレイ タンシー式は(15)式で表現されることになる．同図中にはせん断忍 力比のピーク $\left(\tau / \sigma{ }_{\mathrm{m}}\right)_{\max }$ 後のひずみ軟化過程のデータも含めて (15)式による问帰值線を破線で示した.

$$
\frac{\tau}{\sigma_{m}}=\mathbf{M}+K\left(-\frac{d \varepsilon_{v}}{d \gamma}\right)
$$

ここに, $\mathrm{M}$ は $\left(-\mathrm{d} \varepsilon_{\mathrm{v}} / \mathrm{d} \gamma\right)=\mathbf{0}$ のときのせん断応力比である.

一方, セメント改良砂の $\tau / \sigma^{\prime}{ }_{\mathrm{m}}--\mathrm{d} \varepsilon_{\mathrm{v}} / \mathrm{d} \gamma$ 関係の試験結果に 着目すると, セメント改良砂のせん断応力比 $\tau / \sigma^{\prime}{ }_{\mathrm{m}}$ の值は, 同じダ イレイタンシー比で, 自然砂の $\tau / \sigma{ }^{\prime}{ }_{\mathrm{m}}$ に比べて大きな值を示してい る. また，ダイレイタンシー比のピーク $\left(-\mathrm{d} \varepsilon_{\mathrm{v}} / \mathrm{d} \gamma\right)_{\max }$ までは明 らかに圧密応力の影響を受けており， $\left(-\mathrm{d} \varepsilon_{\mathrm{v}} / \mathrm{d} \gamma\right)_{\max }$ 以降は圧密

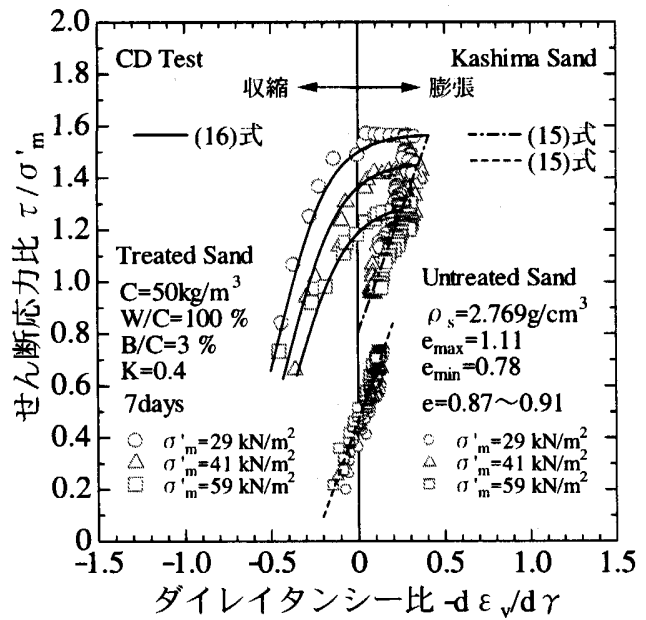

図-3 ストレス・ダイレイタンシー関係

表·1 試料の物理的性質

\begin{tabular}{c|c|c|c|c}
\hline $\begin{array}{c}\text { 土粒子の密度 } \\
\rho_{\mathrm{s}}\left(\mathrm{g} / \mathrm{cm}^{3}\right)\end{array}$ & $\begin{array}{c}\text { 最大間傹比 } \\
\mathrm{e}_{\max }\end{array}$ & $\begin{array}{c}\text { 最小間隚比 } \\
\mathrm{e}_{\text {min }}\end{array}$ & $\begin{array}{c}\text { 等係数 } \\
\mathrm{U}_{c}\end{array}$ & $\begin{array}{c}\text { 平均粒径 } \\
\mathrm{D}_{50}(\mathrm{~mm})\end{array}$ \\
\hline \hline 2.769 & 1.11 & 0.78 & 2.6 & 0.43 \\
\hline
\end{tabular}



図-4 粒径加積曲線

忍力の影響をほとんど受けずに， $\tau / \sigma^{\prime}{ }_{\mathrm{m}}--\mathrm{d} \varepsilon_{\mathrm{v}} / \mathrm{d} \gamma$ 関係は未改 良砂とほぼ同じ傾きの直線で示されるようである。ささらに，せん断 忍力比のピーク $\left(\tau / \sigma^{\prime}{ }_{\mathrm{m}}\right)_{\max }$ とダイレイタンシー比のピーク $\left(-\mathrm{d} \varepsilon_{\mathrm{v}}\right.$ $(\mathrm{d} \gamma)_{\text {max }}$ はほぼ一致していると見なしてもよいことがわかる. 否月 ら:11が行ったシリカ砂およびガラスビーズのセメント固化供試体 に対する一面せん断試験および三軸圧縮試験結果でも同様な傾向が 認められている.

セメント改良砂の体積変化特性をストレス・ダイレイタンシー関 係を用いて表現するには，セメント改良砂の $\tau / \sigma{ }_{\mathrm{m}}{ }^{-}-\mathrm{d} \varepsilon_{\mathrm{v}} / \mathrm{d} \gamma$ 関係を定式化する必要がある，そこで，本論文では，上述したセメ ント改良砂の $\tau / \sigma_{\mathrm{m}}{ }--\mathrm{d} \varepsilon_{\mathrm{v}} / \mathrm{d} \gamma$ 関係の試験結果の特徵を捉える ために, せん断応力比のピーク $\left(\tau / \sigma{ }^{\prime}\right)_{\text {max }}$ までのひずみ硬化過程 を(16)式に示した指数関数で表す.

$\frac{\tau}{\sigma_{m}^{\prime}}=\frac{\left(\tau / \sigma_{m}^{\prime}\right)_{\max }}{1+\alpha \cdot \exp \left[-\beta \cdot\left(-\mathrm{d} \varepsilon_{\mathrm{v}} / \mathrm{d} \gamma\right)\right]}$

ここに， $\alpha, \beta$ は材料定数である.

ひずみ軟化過程である $\left(\tau / \sigma_{m}^{\prime}\right)_{\text {max }}$ 以降は，上述した理由により 
(15)式を適用して材料定数 $\mathrm{K}$ は自然砂と等しくなると仮定した.

図-3 には，(16)式と(15)式に基づくセメント改良砂のストレス・ ダイレイタンシー式をそれぞれ実線と一点鎖線で併せ示した. (16) 式中のパラメータ $\alpha$ は, 試験結果からダイレイタンシー比がゼロに なるときのせん断応力比とせん断忍力比の最大值から(17)式で求め られる. パラメータ $\beta$ は, 代表的な $\sigma^{\prime}{ }_{\mathrm{m}}=41 \mathrm{kN} / \mathrm{m}^{2}$ の試験結果から 非線形最小二乗法の Marquardt 法 32 にによるカーブフィッティング から求めた。

$$
\alpha=\frac{\left(\tau / \sigma_{m}^{\prime}\right)_{\max }}{\left(\tau / \sigma_{m}^{\prime}\right)_{\left(-\mathrm{d} \varepsilon_{v} / d \gamma\right)=0}}-1
$$

\section{4. 排水せん断試䀶のシミュレーション \\ 4.1 解析方法}

摩摖性材料である自然砂と粘着成分を有する摩擦性材料であるセ メント改良砂に対する排水ねじりせん断試験結果 3(1)について, 提案 モデルと双曲線モデルでシミュレーションし，雨モデルを比較した ので，その検討結果について以下に述べる.

排水せん断による両モデルの解析手順を図-5に示す. せん断ひず み $\gamma$ からせん断応力比 $\tau / \sigma^{\prime}{ }_{\mathrm{m}}$ 一せん断ひずみ $\gamma$ 関係とストレス・ダ イレイタンシー関倸を併用することで, 砂とセメント改良砂のせん 断応力 $\tau$ 一せん断ひずみ $\gamma$ 関係と体積ひずみ $\varepsilon_{\mathbf{v}}$ 一せん断ひずみ $\gamma$ 関係を表現するものである.ひずみ軟化挙動における限界状態は, 図-5に示した体積ひずみ増分 $\mathrm{d} \varepsilon 、$ がゼロの状態, すなわちダイレイ タンシー比がゼロになるときの状態である，提案モデルでは，体積 ひずみ增分 $\mathrm{d} \varepsilon_{\mathrm{v}}$ がゼロに達したときのせん断心力比を一定に保持 させることで残留強度（限界状態での強度）を評価する.



図-5 排水せん断の解析手順

\section{2 パラメータの決定方法}

自然砂の初期せん断弾性係数 $\mathrm{G}_{\text {max }}$ は Hardin-Richartの式:3:から 求め, 排水せん断強度 $\tau_{\max }$ はねじりせん断試験結果に基づく Coulomb の破壊基準から求めた. 提案モデルと双曲線モデルの補正 係数 $\mathrm{a}$ と $\mathrm{b}$ および提案モデルの $\mathrm{C}$ と D は Marquardt 法で代表的な $\tau / \sigma{ }_{\mathrm{m}}-\gamma$ 関係の試験結果 $\left(\sigma^{\prime}{ }_{\mathrm{m}}=41 \mathrm{kN} / \mathrm{m}^{2}\right)$ のカーブフィッティ ングから求めた. セメント改良砂の初期せん断弾性係数 $\mathrm{G}_{\max }$ 之排水 せん断強度 $\tau_{\text {max }}$ は筆者らが提案する推定式 30 )から求め, それ以外 のパラメータ a，b，C，Dは自然砂と同様に決定した.

図·6(a)，(b)に，自然砂とセメント改良砂の代表的な $\tau / \sigma{ }_{m}-\gamma$ 関係の試験結果 $\left(\sigma^{\prime}{ }_{\mathrm{m}}=41 \mathrm{kN} / \mathrm{m}^{2}\right)$ と, 提案モデルと双曲線モデル



図-6(a) 自然砂の $\tau / \sigma{ }_{\mathrm{m}}-\gamma$ 関係 のシミュレーション

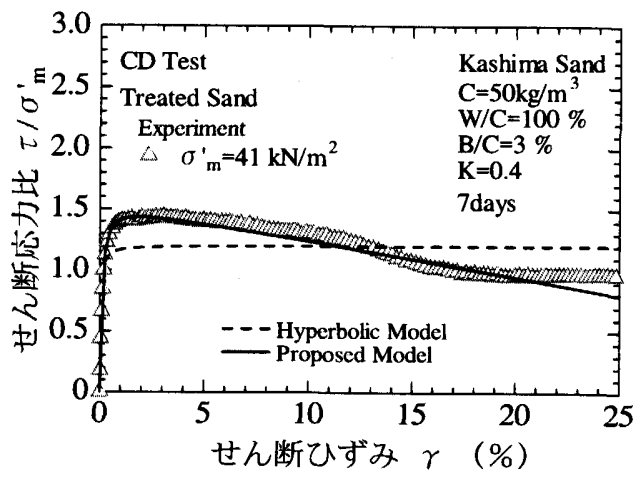

図-6(b) セメント改良砂の $\tau / \sigma{ }_{\mathrm{m}}-\gamma$ 関係 の゙シミュレーション

表·2 解析に用いたパラメータ

\begin{tabular}{|c|c|c|c|}
\hline 試 料 & モデル & & ラメータ \\
\hline \multirow[b]{2}{*}{ 自然砂 } & Hyperbolic Model & $\begin{array}{l}\mathrm{a} \\
\mathrm{b}\end{array}$ & $\begin{array}{l}0.0014 \\
0.9965\end{array}$ \\
\hline & Proposed Model & $\begin{array}{l}\mathrm{a} \\
\mathrm{b} \\
\mathrm{C} \\
\mathrm{D}\end{array}$ & $\begin{array}{l}0.0050 \\
0.3813 \\
0.7765 \\
0.9993\end{array}$ \\
\hline \multirow[b]{2}{*}{$\begin{array}{l}\text { セメント } \\
\text { 改良砂 }\end{array}$} & Hyperbolic Model & $\begin{array}{l}\mathrm{a} \\
\mathrm{b}\end{array}$ & $\begin{array}{l}0.0042 \\
0.8366\end{array}$ \\
\hline & Proposed Model & $\begin{array}{l}\mathrm{a} \\
\mathrm{b} \\
\mathrm{C} \\
\mathrm{D}\end{array}$ & $\begin{array}{l}0.0016 \\
1.1782 \\
1.0332 \\
0.9997\end{array}$ \\
\hline
\end{tabular}

によるシミュレーション結果を示す. 図-6(a)より, 自然砂において は, 双曲線モデルは, せん断初期においては試験結果を良く近似し ているが，最大強度と大ひずみ域におけるひずみ㳄化を表現できて いない，一方，提案モデルは，小ひずみ域から最大強度，そして最 大強度以降のひずみ軟化挙動を比較的良く近似できていることがわ かる. 図-6(b)より，セメント改良砂においては，双曲線モデルは， せん断応力比一せん断ひずみ関係は完全塑性的な挙動を示し，ひず み軟化を表現できていない，一方，提案モデルにおいては，小ひず み域から最大強度, そして最大強度以降のひずみ軟化举動を比較的 良く近似できていることがわかる.

図-6 に示した自然砂とセメント改良砂に対する $\tau / \sigma{ }_{m}{ }^{\prime}-\gamma$ 関係 
のシミュレーション解析結果から求めた提案モデルと双曲線モデル のパラメータ $\mathrm{a}$ と $\mathrm{b}$ および提案モデルの $\mathrm{C}$ と D を表-2 に示す. 後 述するせん断纫力ーせん断ひずみ関倸ならびに体積変化特性のシミ ュレーション解析には, 表-2に示したパラメータを用いている.

\section{3 せん断応力ーせん断ひずみ関保}

提案モデルと補正係数を考慮した双曲線モデルによる各供試体の $\tau / \sigma{ }_{\mathrm{m}}-\gamma$ 関倸のシミュレーション解析結果からせん断応力 $\tau$ を 求め, せん断応力 $\tau$ 一せん断ひずみ $\gamma$ 関係の試験結果と比較した.

図-7(a) と図-7(b)には，相対密度が $\mathrm{Dr} \fallingdotseq 66 \%$ である飽和した自然 砂の異方応力条件（異方圧密忘力比 $\mathrm{K}=0.4$ ） 下での排水ねじりせん 断による試験結果と双曲線モデルと提案モデルのシミュレーション 結果を示す．試験結果は, 滑らかなひずみ硬化一軟化型の心力ーひ ずみ関係を示している，両図から，自然砂においては，広範讲なひ ずみ領域において雨モデルとも試験結果を全般的に良く近似してい ることがわかる，また，提案モデルにおいては，ひずみ軟化挙動を 表現できていることがわかる.

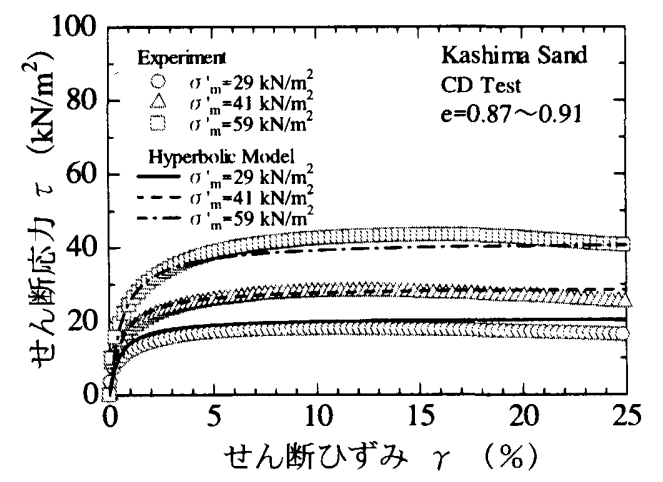

図·7(a) 自然砂の $\tau-\gamma$ 関係のシミュレーション

(Hyperbolic Model)

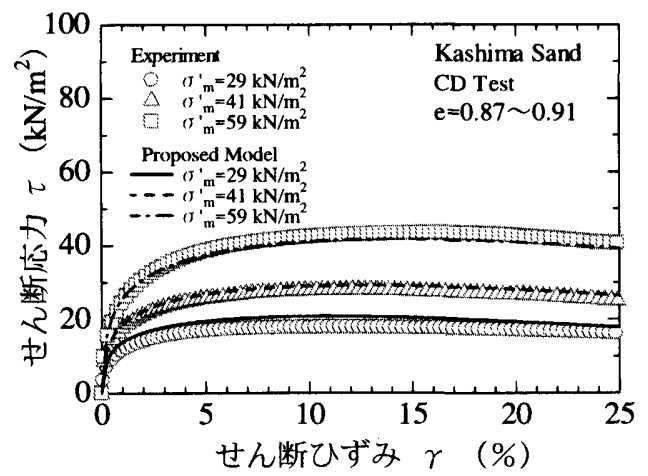

図·7(b) 自然砂の $\tau-\gamma$ 関係のシミュレーション

(Proposed Model)

図-8(a)と図-8(b)には, 自然砂をセメント系固化材により安定処理 した（固化材添加量 $\mathrm{C}=50 \mathrm{~kg} / \mathrm{m}^{3}$, 水 ·固化材重量比 $\mathrm{W} / \mathrm{C}=100 \%$, ベントナイト・固化材重量比 $\mathrm{B} / \mathrm{C}=3 \%$ ） セメント改良砂の異方压密 忍力比 $\mathrm{K}=0.4$ の条件下における排水ねじりせん断による試験結果 と, 双曲線モデルと提案モデルのシミュレーション結果を示す. 図 -8(a)より，双曲線モデルは，せん断初期においては試験結果を良く 近似しているが, 最大強度と大ひずみ域におけるひずみ軟化挙動を

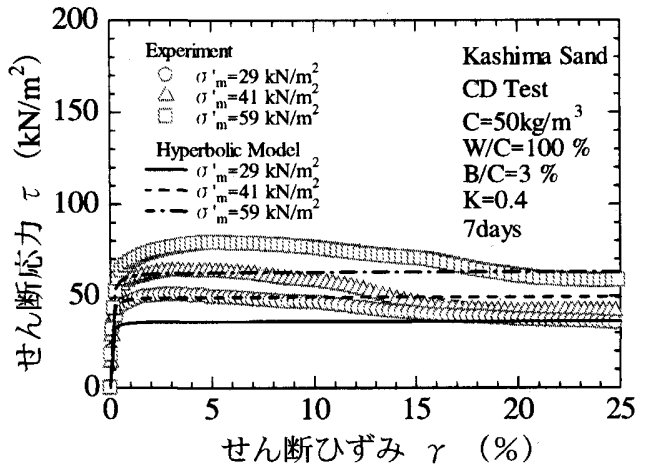

図-8(a) 自然砂の $\tau-\gamma$ 関係のシミュレーション

(Hyperbolic Model)



図-8(b) 改良砂の $\tau-\gamma$ 関係のシミュレーション

(Proposed Model)

表現できていない,一方, 図-8(b)より, 提案モデルは, 最大強度を 過小評価しているものの, 小ひずみ域から最大強度, そして最大強 度以降のひずみ軟化挙動を比較的良く近似できていることがわかる. 試験絓果はせん断ひずみが約 $20 \%$ を越えるとせん断忍力がほぼ一 定の限界状態を呆しているように見えるが, 後述する体積変化は, $\sigma^{\prime}{ }_{m}=41 \mathrm{kN} / \mathrm{m}^{2}$ の試験結果が明確でないものの体積膨張が進行して おり，本試験結果の範囲内では限界状態には到達していないようで ある.

\section{4 体積ひずみーせん断ひずみ関保}

提案モデルと補正俰数を考虑した双曲線モデルによる $\tau / \sigma_{\mathrm{m}}{ }^{\prime}-$



図-9(a) 自然砂の $\varepsilon_{\mathrm{v}}-\gamma$ 関係のシミュレーション (Hyperbolic Model) 


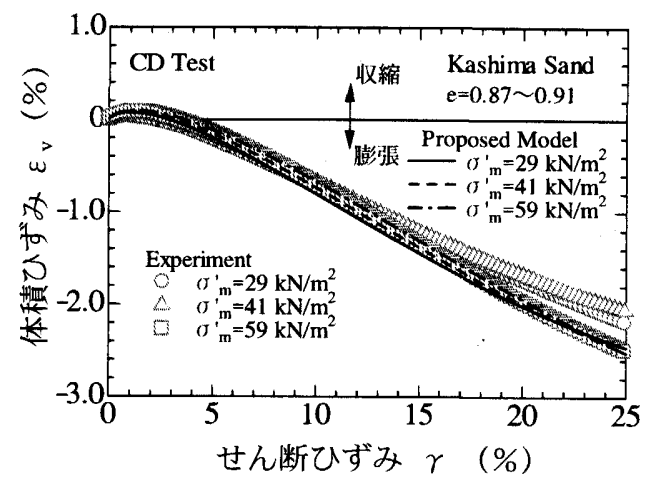

図:9(b) 自然砂の $\varepsilon_{\mathrm{v}}-\gamma$ 関係のシミュレーション (Proposed Model)

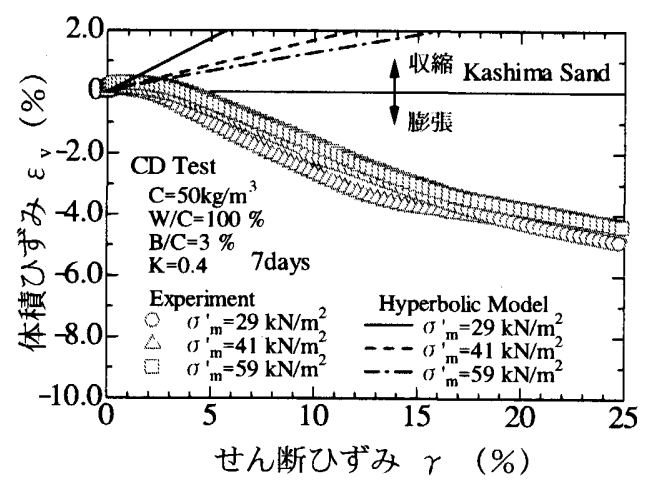

図·10(a) セメント改良砂の $\varepsilon_{\mathrm{v}}-\gamma$ 関係のシミュレーション (Hyperbolic Model)

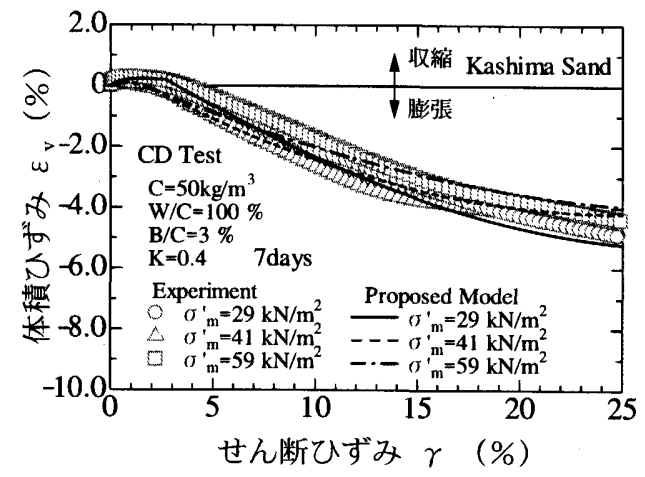

図-10(b) セメント改良砂の $\varepsilon_{\mathrm{v}}-\gamma$ 関係のシミュレーション (Proposed Model)

$\gamma$ 関係のシミュレーション解析結果と, 自然砂とセメント改良砂に 対するストレス・ダイレイタンシー式から体積ひずみ $\varepsilon_{\mathrm{v}}$ を求め, 体 積ひずみ $\varepsilon 、$ 一岁断ひずみ $\gamma$ 関係の試験結果と比較した.

図-9(a), (b)に, 自然砂の $\varepsilon_{v}-\gamma$ 関倸の試験結果と, 双曲線モデ ルと提案モデルによるシミュレーション結果を示す．図-9(a)，(b) より, 自然砂においては, 両モデルとも, せん断に伴う体積収縮か ら体積膨張の変化が捉えられており, 大局的には広範井なひずみ領 域で試験結果と一致していることがわかる.

図-10(a)，(b)には，セメント改良砂に対する $\varepsilon_{\mathrm{v}}-\gamma$ 関係の試験結 果と, 双曲線モデルと提案モデルによるシミュレーション結果を示 した，図-10(a)より，セメント改良砂においては，双曲線モデルで は㐫力ーひずみ関係で最大強度以降のひずみ軟化举動を表現できな いことと, 提案モデルに比べ最人強度が過小評価されることにより, 体積変化特性は収縮倾向のみを示している. 図-10(b)より，提案モ デルでは, せん断に伴う休積収維から体積膨张の変化が捉えられて おり，大局的には公範团なひずみ領域で試験結果を比較的良く近似 していることがわかる.

\section{5. まとめ}

本論文を要約すると以トの通りである.

(1) 地盤材料の公範囲なひずみ領域において，ひずみ硬化のみなら ずひずみ軟化の态力ーひずみ関係を表現できる簡易な非線形 モデルを提案した.

(2) 提案モデルは, 摩擦性材料である砂と粘着成分を有するセメン 卜改良砂に対して，広範囲なひずみ領域でのひずみ硬化一軟化 の伈力ーひずみ関係を表現できることを示した.

(3) 粘着成分を有する摩擦性材料であるセメント改良砂の最大強 度までのひずみ硬化過程のストレス・ダイレイタンシー式を指 数関数((16)式)で表した.

(4) 提案した応力ーひずみ関係の非線形モデルとストレス・ダイレ イタンシー式を併用することにより砂とセメント改良砂のダイ レイタンシー特性を表現できることを示した.

本論文に示したひずみは，供試体の平均ひずみであり，最大強度 後のひずみ軟化現象で発達する供試体の局所的な変形, すなわちせ ん断首におけるひずみではなく, 単調載荷試験による砂とセメント 改良砂に対する巨視的な排水せん断挙動のシミュレーション解析結 果をまとめたものである．また，本論文の検討は限られた試験結果 に基づいたものであり, 今後は, 非排水せん断挙動の解析, 繰这し 載荷試験，せん断首における心力ーひずみ関倸に提案モデルを適用 して構成式の一般性を検討しなければならない。

\section{【参考文献】}

1)龍岡文夫, 龇谷啓 : 地盤材料の広い範囲のひずみでの応力・ひずみ関倸式に つて, 第 26 回土質工学研究発表会, pp.537-540, 1991.

2)Kondner,R.L.: Hyperbolic Stress-Strain Response : Cohesive Soils, J.Soil Mech. and Found. Div.,ASCE., Vol.89,No.SM1,pp.115·143, 1963.

3)Kondner,R.L. and Zelasco,J.S.: A Hyperbolic Stress'Strain Formulation for Sands,Proc.2 nd Pan Am. Conf. on Soil Mech. and Found. Eng., Brazil, Vol.1,pp.289-324,1963.

4)龍岡文夫, 淺谷啓: 三軸試験と原位圈試験法との関連 (変形特性について), 三軸試験方法に関寸るシンポジウム発表論文集, pp.39·84, 1991.

5)Hayashi,H. and Sugahara,T. : Modeling of the Nonlinear Shear Stress. Strain Behavior of Soils, 第 8 回日本地震 工学シンポジウム, pp.777・782, 1990.

6)Prevost,J.H. and Keane,C.M. : Shear Stress-Strain Curve Generation from Simple Material Parameters, Jour. Of Geotecnical Engineering, 116-8,pp.1255-1263, 1990.

7)Griffiths,D.V. and Prevost,J.H. : Stress Strain Curve Generation from Simple Triaxial Parameters, Proc. Int. Jour. for Numerical and Analytical Methods in Geomechanics,Vol.14,pp.587-594,1990.

8)Tatsuoka,F. and Shibuya,S. : Deformation Characteristics of Soils and Rocks from Field and Laboratory Tests, Theme Lecture 1,Proc.Ninth Asian Regional Conference on Soil Mechanics and Foundation Engineering,Vol.2,pp.101·170,1992

9)Duncan,J.M. and Chang,C.Y. : Nonlinear Analysis of Stress and Strain 
in Soils,Jour.SMF Div., ASCE, Vol.96,No.SM5,pp.1629·1653,1970.

10)Towhata,I. and Ishihara,K. : Modelling Soil Behavior under Principal Stress Axes Rotation, Proc. Fifth International Conference on Numerical Methods in Geomechanics,Nagoya,pp.523-530, 1985.

11)Iwan,W.P. : On a Class of Models for the Yielding Behavior of Continuous and Composite Systems, Journal of Applied Mechanics, Vol.34,No.E3,pp.612-617,1967.

12)Jardine,R.J.,Potts,D.M.,St.John,H.D. and Hight,D.W. : Some Practical Applications of a Non-Linear Ground Model, Proc. of 10th European Regional Conference on SMFE,Firenze, Vol. I ,pp.223·228,1991.

13)Goto,S.,Burland,J.B. and Tatsuoka,F. : Non-Linear Soil Model with Various Strain Levels and Its Application to Axisymmetric Excavation Problem, Journal of the Japanese Geotechnical Society, Soils and Foundations, Vol.39, No.4, pp.111·119,1999

14)Ramberg,W. and W.R.Osgood : Description of Stress-Strain Curves by Three Parameters, Technical Note 902,NACA,July, 1943

15)Jennings,P.C. : Periodic Response of a General Yielding Structure, J. Eng. Mech. Div., ASCE, Vol,90, No.EM 2,April, 1964.

16)Nishi,K. and Esashi,Y. : Stress-Strain Relationships of Sand based on Elasto·Plasticity Theory,土木学会㖮文報告集,No.280,pp.111·122, 1978.

17)中井照夫, 松岡元: 3主応力下の土のせん断举動に関才る統一的解釈, 土木 学会論文報告集, 第 303 号, pp.65·77, 1980.

18)Hirai,H.,Takahashi.M. and Yamada,M.: An Elastic Plastic Constitutive Model for the Bebavior of Improved Sandy Soils, Japanese Society of Soil Mechanics and Foundation Engineering, Soils and Foundations, Vol.29, No.2, pp.68-84, 1989

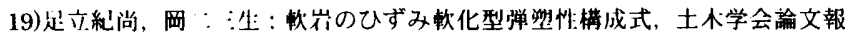
先集, 第 445 号, III-18, pp.9-16, 1992

20)Gens,A. and Nova,R. : Conceptual Bases for a Constitutive Model for Bonded Soils and Weak Rocks,Proc.,Int.Symp.on Geotech.Engrg.of Hard Soils-Soft Rocks, Vol.1,Balkema,Rotterdam,The Netherlands,pp 485•494, 1993.

21)Rowe, P. W. : The Stress-Dilatancy Relation for Static Equilibrium of an Assembly of Particles in Contact, Proc. Royal Sciety London, Series A,Vol.269,pp.500-527, 1962 .

22)Hardin,B.O. and Drnevich,V.P. : Shear Modulus and Damping in Soils : Design Equations and Curves, Proc.ASCE, Jour.SMFD, Vol.98,No.SM7, pp.667-692,1972.

23)Kohata,Y.,Tatsuoka,F.,Wang,L.,Jiang,G.J.,Hoque,E. and Kodaka,T. : Modelling the Non-Linear Deformation Properties of Stiff Geomaterials, Geotechnique, Vol.47,No.3, pp.563-580,1997.

24)能岡文夫，木幡行宏：ベディングエラー，士と基礎，Vol.42,No.9,Ser. No.440, pp.53-55, 1994 .

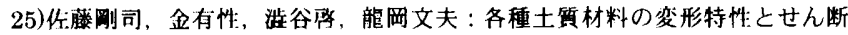
強度の関倸、第 25 回土兵厂学研究発表会,pp.715-718,1990.

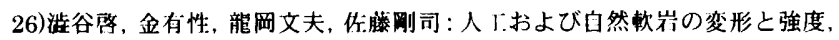
土と基礎，Vol.38,No.7,Ser.No.390,pp.132-137,1990.

27)Kulhawy,F.H. : Stress Deformation Properties of Rock and Rock Discontinuities, Engineering Geology,9,pp.327-350,1975.

28)Oda,M. : The Mechanism of Fabric Changes during Compressional Deformation of Sand, Japanese Society of Soil Mechanics and Foundation Engineering, Soils and Foundations, Vol.12, No.2, pp.118,1972 .

29)Shamoto,Y.,Zhang,J.-M. and Kusukame,T. : A Simple Method for Triaxial Strain Path Testing, Journal of the Japanese Geotechnical Society, Soils and Foundations, Vol.36, No.2, pp.129-137,1996.

30)山田雅一, 安達俊夫: 中空対じりせん断によるセメント改良砂の強度・変形特性 ·排水せん断強度と微小ひずみでの変形特性·, 日本建築学会構造系論文集, 第 570 号, pp.107·114, 2003.

31)香月大輔, 中田幸男, 兵藤正幸, 吉本憲正, 村田秀一:ダイレイタンシーに着 目したセメント固化粒状体のせん断強度特性の評価, 第5回地盤改良シンボジ ウム論文集, pp.147·152, 2002.

32)中川徹, 小柳義夫:最小二乗法による実験データ解析 ブログラム SALS, 東京
大学出版会, 1986.

33)Hardin,B.O. and F.E.Richart Jr. : Elastic Wave Velocities in Granular Soils,Jour. of SMF Div.,Proc. ASCE,Vol.89,No.SM1,Proc. Paper 3407, pp.33-65, 1963 .

34)山田雅一, 安達俊夫, 旭山敦: セメン下系砂質改良土の強度・変形特性(その7, ストレス・ダイレタシー関係)，日本建築学会大会学術講演梗概集，B-1， pp.687·688,2001.

35)山田雅一, 安達俊夫: 広簕囲なひずみ領域におううるメント改良砂の応カーひ ず为関係, 第 37 回地盤工学研究発表会, pp.811·812,2002.

36)山田雅一, 安達俊夫:広範囲なひずみ領域におう批盤材料の応力ーひずみ 関係, 日本建築学会大会学術講演梗概集, B-1, pp. 615·616, 2002.

37)山田雅一, 安達俊夫: 広範囲なひずみ領域に㧍ける地盤材料の応力ーひずみ 関係-砂とセメント改良砂のダイレイタンシー特性・, 日本建築学会大会学術講 演梗概集, B·1, pp.399·400, 2003.

（2005年 4 月 10 日原稿受理，2005年10月14日採用決定） 